\title{
Depurð meðal skólabarna á Íslandi
}

\begin{abstract}
Ársæll Arnarsson
Abstract Um höfundinn $>$ About the author $\quad$ Heimildir

Sú skoðun að kynslóðin sem nú vex úr grasi sé útsettari fyrir depurð en pær sem á undan hafa komið er útbreidd bæði á meðal almennings og fagaðila. Markmið pessarar rannsóknar var að skoða hvernig algengi daglegrar depurðar íslenskra unglinga breyttist á árunum 2006-2018 og hvaða pættir tengdust daglegri depurð í fyrirlögn árið 2018. Notuð voru gögn úr rannsókninni Heilsa og lífskjör skólabarna (e. Health Behaviour in School-Aged Children - HBSC). Frá árinu 2006 hefur pessi rannsókn verið lögð fyrir í 6., 8. og 10. bekk á Íslandi og í síðustu fyrirlögn veturinn 2017-2018 fengust svör frá 7.159 nemendum. Niðurstöðurnar sýndu að tíðni daglegrar depurðar hafði aukist um priðjung á tímabilinu, eða úr 5,8\% árið 2006 i 7,6\% árið 2018. Mjög slæm fjárhagsstaða fjölskyldu og svefnörðugleikar á hverri nóttu 25-földuðu líkurnar á pví að unglingar fyndu fyrir depurð á hverjum degi. Að finnast maður vera alltof feitur 13-faldaði líkurnar, tíð áfengisneysla tífaldaði pær og einelti oft í viku nífaldaði pær. Peir unglingar sem skilgreindu kyn sitt sem ,,annað“ en strákur eða stelpa, voru átta sinnum líklegri en jafnaldrar peirra til að finna fyrir depurð daglega. Sama átti við um pá sem reyktu sígarettur eða kannabis reglulega. Fimmföldun á áhættu sást meðal peirra sem notuðu rafrettur reglulega, áttu slök tengsl við foreldra eða við skóla. Slök vinatengsl prefölduðu líkurnar. Aðrir pættir sem um pað bil tvöfölduðu líkurnar voru annað fæðingarland unglings en Ísland og fæðingarland foreldra hans. Stelpur voru líka tvöfalt líklegri en strákar til að finna fyrir depurð nær daglega. Enn aðrir pættir höfðu veikari fylgni. Dannig voru 10. bekkingar helmingi líklegri en 6. bekkingar til að finna fyrir depurð daglega og óeðlileg skjánotkun jók líkurnar um 60\%. Af niðurstöðunum má ráða að tíðni daglegrar depurðar meðal íslenskra unglinga hefur sannarlega aukist. Ýmsir pættir hafa fylgni við depurð unglinga en líklegast er að aukning í svefnörðugleikum skýri mest af peirri aukningu sem sést.
\end{abstract}

Efnisorð: Unglingar, depurð, skólinn, foreldrar, vinir

\section{Inngangur}

Faraldsfræðilegar rannsóknir benda til að um tíundi hver einstaklingur glími við geðraskanir í barnæsku eða á unglingsaldri. Dessar raskanir geta haft mjög skaðleg og víðtæk áhrif á heilsu, vellíðan og framtíðarmöguleika ungmenna (Collishaw, 2015) og eru auk pess yfirleitt langvinnar (Thapar, Collishaw, Pine og Thapar, 2012). Drátt fyrir að mikil áhersla hafi verið lögð á rannsóknir og forvarnaraðgerðir er sú skoðun útbreidd á meðal foreldra, kennara og heilbrigðisstarfsfólks að sú kynslóð sem nú vex úr grasi sé útsettari fyrir geðrænum vandamálum en pær sem á undan hafa komið. Alpjóðlegar rannsóknir hafa sýnt fram á aukningu í greiningum og meðferðum geðraskana (Collishaw, 2015) og hérlendis sýna tölur hrakandi geðheilsu meðal ungs fólks (Sigrún 
Daníelsdóttir, Védís Helga Eiríksdóttir og Salbjörg Bjarnadóttir, 2017), einkum stúlkna (Margrét Lilja Guðmundsdóttir o.fl., 2016). Í Svípjóð hefur hlutfall 13 og 15 ára unglinga sem glíma við viðvarandi sállíkamleg einkenni tvöfaldast á síðastliðnum 30-40 árum (Folkhälsomyndigheten, 2018).

Ýmsar breytingar á 21. öldinni hafa verið nefndar sem hugsanlegar skýringar á lakari geðheilbrigði peirrar kynslóđar sem nú er á unglingsaldri (Bor, Dean, Najman og Hayatbakhsh, 2014). Ýmsar breytingar í fjölskyldumynstri geta valdið aukinni tíðni geðrænna vandamála á meðal unglinga, svo sem fjölgun einstæðra foreldra, átök innan fjölskyldna (Sweeting, West, Young og Der, 2010) og geðræn vandamál foreldra (Fatori, Bordin, Curto og de Paula, 2013). Dá hefur að sjálfsögðu verið bent á að sá gríðarmikli tími sem ungmenni verja nú fyrir framan skjái, á netinu og á samfélagsmiðlum, kunni að hafa sitt að segja (Carli o.fl., 2014). Einnig hefur verið sýnt fram á að efnahagslegur ójöfnuður eykur geðræn vandamál unglinga (Langton, Collishaw, Goodman, Pickles og Maughan, 2011), sem og aukið álag í nútíma skólaumhverfi (Sweeting o.fl., 2010).

Dó að pað sé eðlilegt að upplifa depurð endrum og sinnum á unglingsárum, eins og á öðrum æviskeiðum, pá getur langvarandi geðlægð á pessum tíma verið fyrirboði alvarlegs og endurtekins punglyndis, kvíða, vímuefnaneyslu og sjálfsvígshegðunar (Fergusson, Boden og Horwood, 2007). Баð hversu útsettir unglingar eru fyrir alvarlegri depurð getur skýrst af fjölda samverkandi pátta sem tengjast erfðum, proska og félagslegum aðstæðum, t.d. einelti (Maughan, Collishaw og Stringaris, 2013). Par að auki eru sterk tengsl á milli depurðar unglinga og depurðar foreldra peirra, einkum og sér í lagi mæðra (Graham og Easterbrooks, 2000).

Niðurstöður framsærra rannsókna benda til pess að of lítill svefn sé oft undanfari depurðar hjá ungu fólki (Conklin, Yao og Richardson, 2018). Í einni slíkri, par sem fylgst var með 3.134 einstaklingum á aldrinum 11 til 17 ára, kom í ljós að peir sem voru vansvefta í upphafi rannsóknarinnar (sváfu minna en 6 klst. á nóttu) voru 40\% líklegri til að hafa einkenni punglyndis ári síðar. Dessi áhrif voru óháð aldri, kyni, fjárhagsstöðu fjölskyldu og pví hvort punglyndiseinkenni voru til staðar í upphafi (Roberts, Roberts og Duong, 2009). Aðrar rannsóknir hafa einungis fundið petta samband á meðal unglingsstúlkna en ekki hjá drengjum (Conklin o.fl., 2018).

Markmið pessarar rannsóknar var að skoða algengi daglegrar depurðar íslenskra nemenda í 6., 8. og 10. bekk, hvernig sú tíðni hefur breyst á árunum 2006-2018 og hvaða pættir tengdust daglegri depurð í fyrirlögn HBSC (e. Health Behaviour in School-Aged Children - HBSC) 2018.

\section{Аðferð}

\section{HBSC-rannsóknin}

Heilsa og lífskjör skólabarna er fjölpjóðleg rannsókn, studd af Alpjóðaheilbrigðismálastofnunin ni (WHO), par sem unglingar eru spurðir um ýmsa pætti varðandi heilsu, líðan og félagslegar aðstæður (Inchley o.fl., 2016). Fyrsta fyrirlögnin fór fram veturinn 1983-1984 og hún hefur síðan verið endurtekin fjórða hvert ár. Frá árinu 2006 hefur pessi rannsókn verið lögð fyrir á Íslandi. Síðasta fyrirlögn var veturinn 2017-2018 og fengust pá svör frá 7.159 nemendum. Fjöldi pátttakenda í fyrri fyrirlögnum er sýndur í töflu 1.

\section{Framkvermd}

Áður en gagnasöfnun hófst veturinn 2017-2018 var spurningalistinn sendur, ásamt rannsóknaráætlun, til Persónuverndar og Vísindasiðanefndar Háskóla Íslands. Engar athugasemdir voru gerðar við fyrirhugaða framkvæmd. Að pví loknu voru sömu upplýsingar sendar öllum skólastjórum á Íslandi sem höfðu nemendur í 6., 8. eða 10. bekk og pess óskað að peirra skólar tækju pátt. Síðan var öllum foreldrum og forráðamönnum sent kynningarbréf og peim gefið tækifæri til að hafna pátttöku sinna barna. 
Fyrirlagning spurningalistans var með rafrænum hætti veturinn 2017-2018. Borð nemenda voru færð í sundur til pess að tryggja að svarendur sæju ekki svör annarra og svo opnaði hver og einn sinn lista á sinni tölvu. Í upphafi var stutt lýsing á rannsókninni ásamt skýrum skilaboðum pess efnis að jafnvel pótt foreldrar peirra og skólayfirvöld hefðu gefið leyfi, pá væri nemendum sjálfum algjörlega frjálst að neita pátttöku eða að sleppa að svara ákveðnum spurningum. Pá var ítrekað að um nafnlausa könnun væri að ræða. Lýsingu á gagnasöfnun fyrri fyrirlagna sem fóru fram með skriflegum hætti má lesa annars staðar (Arnarsson, Sveinbjornsdottir, Thorsteinsson og Bjarnason, 2015).

\section{Mcelitaki}

Upplifun unglinganna af depurð var metin með spurningunni: „Hversu oft hefur pú fundið fyrir depurð á síðustu sex mánuðum?" Svarmöguleikarnir voru fimm: 1) Hér um bil daglega, 2) Oftar en einu sinni í viku, 3) Um pað bil vikulega, 4) Um pað bil mánaðarlega, og 5) Sjaldan eða aldrei. Spurningin er hluti af „Symptom checklist“ alpjóðlegu HBSC-rannsóknarinnar og hefur verið lögð fyrir frá árinu 1986. Rannsókn Haugland og Wold, (2001) sýndi að unglingar gátu skilið og greint frá líðan sinni með réttmætum hætti pegar peir voru beðnir um að svara pessari spurningu. Í rannsókninni kom einnig fram að endurprófunaráreiðanleikinn var 0,67.

Í fyrirlögninni veturinn 2017-2018 var gert ráð fyrir pví að unglingarnir gætu svarað spurningunni um kyn með öðrum hætti en hinum hefðbundna tvíkosta möguleika sem pangað til hafði tíðkast. Auk pess að geta merkt við 1) Strákur eða 2) Stelpa, var hægt að merkja við 3) Annað.

Nemendur voru spurðir um hversu oft peir hefðu verið lagðir í einelti. Í listanum voru fimm svarmöguleikar frá 1) Aldrei til 5) Nokkrum sinnum í viku. Við úrvinnslu gagna var notast við skilgreiningu Olweus (1996), par sem einelti er skilgreint pegar atvik í pá veru verða 2-3 sinnum í mánuði eða oftar.

Allir nemendur sem tóku pátt voru spurðir um áfengisdrykkju sína. Auk pess voru 10. bekkingar spurðir um reynslu sína af neyslu kannabisefna.

Til að meta líkamsmynd pátttakenda var lögð fyrir spurningin; „Finnst pér pú vera...?“ Svarmöguleikarnir voru fimm: 1) Alltof grönn/grannur, 2) Aðeins of grönn/grannur, 3) Um pað bil mátuleg(ur), 4) Aðeins of feit(ur), 5) Alltof feit(ur).

Einkenni um óeðlilega mikla notkun samfélagsmiðla var mæld með Social Media Disorder Scale (van den Eijnden, Lemmens og Valkenburg, 2016), par sem svarendur eru beðnir um að taka afstöðu til níu fullyrðinga sem lýsa erfiðleikum tengdum slíkum miðlum. Deir sem svöruðu fimm eða fleiri fullyrðingum játandi töldust nota pá með óeðlilegum hætti.

Nemendur voru einnig spurðir um hversu oft peir ættu í erfiðleikum með að sofna. Svarmöguleikarnir voru: 1) Hér um bil daglega, 2) Oftar en einu sinni í viku, 3) Um pað bil vikulega, 4) Um pað bil mánaðarlega eða 5) Sjaldan eða aldrei.

Til pess að bera kennsl á pá unglinga sem hefðu slök tengsl við foreldra sína voru notaðar fjórar einfaldar spurningar. Dær könnuðu tengsl við líffræðilega foreldra og einnig stjúptengsl ef pau voru fyrir hendi. Nemendurnir voru beðnir um að meta hversu auðvelt peir ættu með að tala um pað sem ylli peim áhyggjum við föður sinn, móður sína, stjúpföður eða stjúpmóður. Svarmöguleikarnir voru fimm: 1) Mjög auðvelt, 2) Auðvelt, 3) Erfitt, 4) Mjög erfitt, 5) Á ekki við eða hitti ekki viðkomandi. Svörin við spurningunum voru kóðuð pannig að gildið 1 táknaði slök tengsl og í pann flokk féllu peir unglingar sem sögðust eiga erfitt eða mjög erfitt með að tala við foreldra sína. Deir unglingar sem sögðust ekki eiga eða ekki hitta foreldra voru einnig settir í pennan flokk. Deir sem sögðust eiga auðvelt með að tala við foreldra fengu gildið $2 \mathrm{sem}$ táknar góð tengsl og ef samskiptin voru mjög auðveld fengu peir gildið 3. Kóðunin var hins vegar aðallega gerð til pess að reikna út samtölu fyrir tengsl við foreldra, p.e. að skoða ekki einungis 
áhrif eins foreldris heldur tveggja eða fleiri par sem pað átti við. Í peim útreikningi var stuðst við einfalda formúlu Andersen og Dæhlen (2017), par sem gildin frá 1 upp í 3 eru lögð saman og deilt í með tveimur ef um tvo foreldra er að ræða, premur ef foreldrarnir eru prír og fjórum ef unglingurinn hefur metið samskipti við föður, móður, stjúpföður og stjúpmóður. •að pýðir t.d. að unglingur sem á tvo foreldra og segist vera í góðum tengslum við stjúpföður (gildið 2) og mjög góðum tengslum við móður (gildið 3) fær samtöluna 2,5. Unglingur sem á prjá foreldra og segist vera í mjög góðum tengslum við móður og stjúpmóður (tvisvar sinnum gildið 3) en slökum tengslum við föður (gildið 1) fær samtöluna 2,3. Unglingur sem á tvö heimili með tveimur settum af foreldrum og metur t.d. tengsl við föður og stjúpmóður slök (tvisvar sinnum gildið 1) en tengsl við móður og stjúpföður góð (tvisvar sinnum gildið 2) fær samtöluna 1,5.

Samtölur undir 1,6 voru metnar sem merki um slök tengsl við foreldra, á meðan pær sem lentu á milli 1,6 upp í 2,2 voru túlkaðar sem góð tengsl. Allar samtölur yfir 2,2 voru skilgreindar pannig að unglingurinn hefði mjög góð tengsl við foreldra sína.

Tengsl unglinga við skólann voru metin út frá fjórum spurningum úr HBSC-könnuninni. Prjár voru fullyrðingar um kennara og áttu nemendurnir að segja hvort peir væru 1) Mjög sammála peim, 2) Sammála, 3) Hvorki sammála né ósammála, 4) Ósammála eða 5) Mjög ósammála. Fullyrðingarnar prjár voru svohljódandi: a) Kennararnir taka mér eins og ég er, b) Mér finnst kennurunum vera annt um mig sem einstakling og c) Ég treysti kennurunum mínum mjög vel. Svarið við hverri fullyrðingu var metið pannig að peir unglingar sem voru mjög sammála voru metnir í mjög góðum tengslum við skólann og fengu gildið 3 fyrir hvert svar. Peir unglingar sem sögðust vera sammála voru metnir í góðum tengslum við skólann og hvert slíkt svar fékk gildið 2. Unglingar sem svöruðu með öðrum hætti voru hins vegar taldir í slökum tengslum og fengu pau svör gildið 1. „Hvernig líkar pér í skólanum?““ var svo fjórða spurningin sem notuð var til að meta tengslin. Við henni voru gefnir fjórir svarmöguleikar: 1) Mér líkar mjög vel í skólanum, 2) Mér líkar pokkalega í skólanum, 3) Mér líkar ekki vel í skólanum og 4) Mér líkar alls ekki vel í skólanum. Pegar pessi spurning var kóðuð fékk fyrsti svarmöguleikinn gildið 3, annar fékk gildið 2 en priðju og fjórðu svarmöguleikarnir voru kóðaðir sem 1. Kóðunin var síðan notuð pess að reikna út samtölu fyrir tengsl við skólann. Í peim útreikningi var stuðst við formúlu Andersen og Dæhlen (2017), par sem gildin frá 1 upp í 3 eru lögð saman og deilt í með fjölda svara sem í flestum tilfellum voru fjögur. Samtölur undir 1,6 voru metnar sem merki um slök tengsl við skóla á meðan pær sem lentu á milli 1,6 og 2,2 voru metnar til vitnis um góð tengsl. Allar samtölur yfir 2,2 voru skilgreindar pannig að unglingurinn hefði mjög góð tengsl við skólann sinn.

Tengsl unglinga við vini sína voru metin út frá afstöðu peirra til fjögurra fullyrðinga úr HBSCkönnuninni: a) Vinir mínir reyna virkilega að hjálpa mér, b) Ég get treyst á vini mína pegar eitthvað fer úrskeiðis, c) Ég á vini sem deila með mér gleði og sorg og d) Ég get talað við vini mína um mín vandamál. Svarið við hverri spurningu var sett upp á sjö stiga kvarða par sem „1“ táknaði „Mjög ósammála“ og „7“ " pýddi „Mjög sammála“. Meðaltöl svara allra nemenda við spurningunum fjórum var reiknað og síðan endurkóðað pannig að peir sem svöruðu pessum spurningum að meðaltali með 7 á kvarðanum voru metnir í mjög góðum tengslum við vini sína og fengu gildið 3. Ef meðaltalið var á milli 5 og 6 var litið svo á að um góð vinatengsl væri að ræða og kóðað sem 2. Ef meðaltalið úr svörunum var hins vegar 4 eða lægra var pað flokkað sem slök félagstengsl og kóðað sem 1. Dessi kóðun frá 1 upp 13 var sömuleiðis gerð að fyrirmynd Andersen og Dæhlen (2017).

\section{Tölfrað i}

Í fyrirlögnunum 2006-2014 voru gögnin skönnuð inn, en árið 2018 var um rafræna fyrirlögn að ræða. Öll gögn eru send til Data Management Center sem staðsett er í Háskólanum í Bergen og par eru pau hreinsuð og ónóg svör fjarlægð. Tölfræðileg úrvinnsla var framkvæmd með IBM SPSStölfræðiforritinu fyrir Windows (útgáfa 24.0. Armonk, NY: IBM). Lýsandi tölfræði var notuð og kí-kvaðrat reiknað til að rannsaka tengsl á milli flokka nafnbreyta. Lógistísk aðhvarfsgreining var gerð til að skoða hlutfallsleg tengsl frumbreyta við fylgibreytuna (dagleg depurð). 


\section{Niðurstöður}

Tafla 1 sýnir hlutfall nemenda í 6., 8. og 10. bekk sem sagðist upplifa depurð daglega. Bornar eru saman niðurstöður frá HBSC-fyrirlögnum árin 2006, 2010, 2014 og 2018. Árið 2006 sögðust 5,8\% nemenda upplifa depurð daglega. Árið 2018 var petta hlutfall 7,6\%. Detta er priðjungsaukning. Talsverður breytileiki var pó í pessari próun pegar skipt hafði verið eftir kyni og bekkjardeild. Eins og sést 1 töflu 1 hefur svarhlutfall rannsóknarinnar verið með ágætum pó verulega hafi dregið úr pví í síðustu fyrirlögn par sem fleiri skólar kjósa að taka ekki pátt.

Tafla 1. Tíðni daglegrar depurðar á meðal íslenskra unglinga 2006-2018 - \%(N)

\begin{tabular}{|c|c|c|c|c|c|}
\hline & & 2006 & 2010 & 2014 & 2018 \\
\hline \multicolumn{6}{|l|}{ Strákar } \\
\hline & 6. bekk & $3,7(70)$ & $4,0(72)$ & $5,0(83)$ & $4,1(46)$ \\
\hline & 8. bekk & $3,4(65)$ & $2,8(53)$ & $4,0(74)$ & $4,8(58)$ \\
\hline & 10. bekk & $3,3(31)$ & $3,9(68)$ & $9,5(163)$ & $5,9(63)$ \\
\hline \multicolumn{6}{|l|}{ Stelpur } \\
\hline & 6. bekk & $6,7(125)$ & $6,0(174)$ & $5,9(194)$ & 7,9(87) \\
\hline & 8. bekk & $8,3(154)$ & $5,0(214)$ & $8,8(226)$ & $9,1(113)$ \\
\hline & 10. bekk & $10,2(95)$ & $13,4(228)$ & $8,6(231)$ & $11,6(127)$ \\
\hline Heild & & $5,8 \%$ & $5,5 \%$ & $7,0 \%$ & $7,6 \%$ \\
\hline Svarhlutfall & & $86 \%$ & $89(7.360)$ & $84(11.019)$ & $54(7.159)$ \\
\hline
\end{tabular}

Dær niðurstöður sem hér fara á eftir miðast allar við fyrirlögnina veturinn 2017-2018. Af peim sem svöruðu spurningalistanum veturinn 2017-2018 voru 3.530 strákar (49,4\%), 3.498 stelpur (49,0\%) og 118 nemendur sem skilgreindu sig ekki eftir tvíkosta svarmöguleikum (1,7\%). Unglingarnir voru einnig spurðir um fæðingarland sitt og foreldra sinna. Alls sögðust $5.695(81,9 \%)$ peirra sem svöruðu spurningunni vera fæddir á Íslandi líkt og foreldrarnir, 966 (13,9\%) voru annað hvort fæddir á Íslandi en báðir foreldrarnir voru erlendir eða voru fæddir erlendis og annað foreldrið var íslenskt, og 290 (4,2\%) voru fæddir erlendis og báðir foreldrarnir sömuleiðis. Sömuleiðis voru peir beðnir um að meta fjárhagsstöðu fjölskyldu sinnar miðað við aðrar og sögðu 2.806 (41,0\%) að hún væri mjög góð, 2.755 (40,2\%) að hún væri góð, 1.131 (16,5\%) sögðu hana miðlungs, 118 $(1,7 \%)$ sögðu hana slæma og 41 mjög slæma (0,6\%). Samkvæmt skilgreiningu Olweushöfðu 6,2\% svarenda orðið fyrir einelti. Alls sögðust 5.658 aldrei hafa bragðað áfengi, en 1.116 höfðu einhvern tíma prófað pað. Auk pess voru 10. bekkingar spurðir um reynslu sína af neyslu kannabisefna og reyndust 183 hafa prófað en 1.970 aldrei snert slíkt. Unglingar í 10. bekk voru sömuleiðis spurðir um hvort peir hefðu einhvern tíma haft samfarir. Alls sögðust 551 hafa prófað pað en 1.594 svöruðu neitandi. Alls töldust 480 eða 7,4\% nemenda falla undir skilgreiningu á óeðlilegri notkun samfélagsmiðla.

Á mynd 1 sést fylgni fjárhagsstöðu fjölskyldunnar við tíðni daglegrar depurðar. Mjög sterk tengsl eru á milli pessara tveggja breyta. Tíðni daglegrar depurðar á meðal peirra unglinga sem telja fjárhagsstöðu fjölskyldu sinnar vera mjög góða er 5,4\%, en 58,5\% á meðal peirra sem telja að hún sé mjög slæm. 


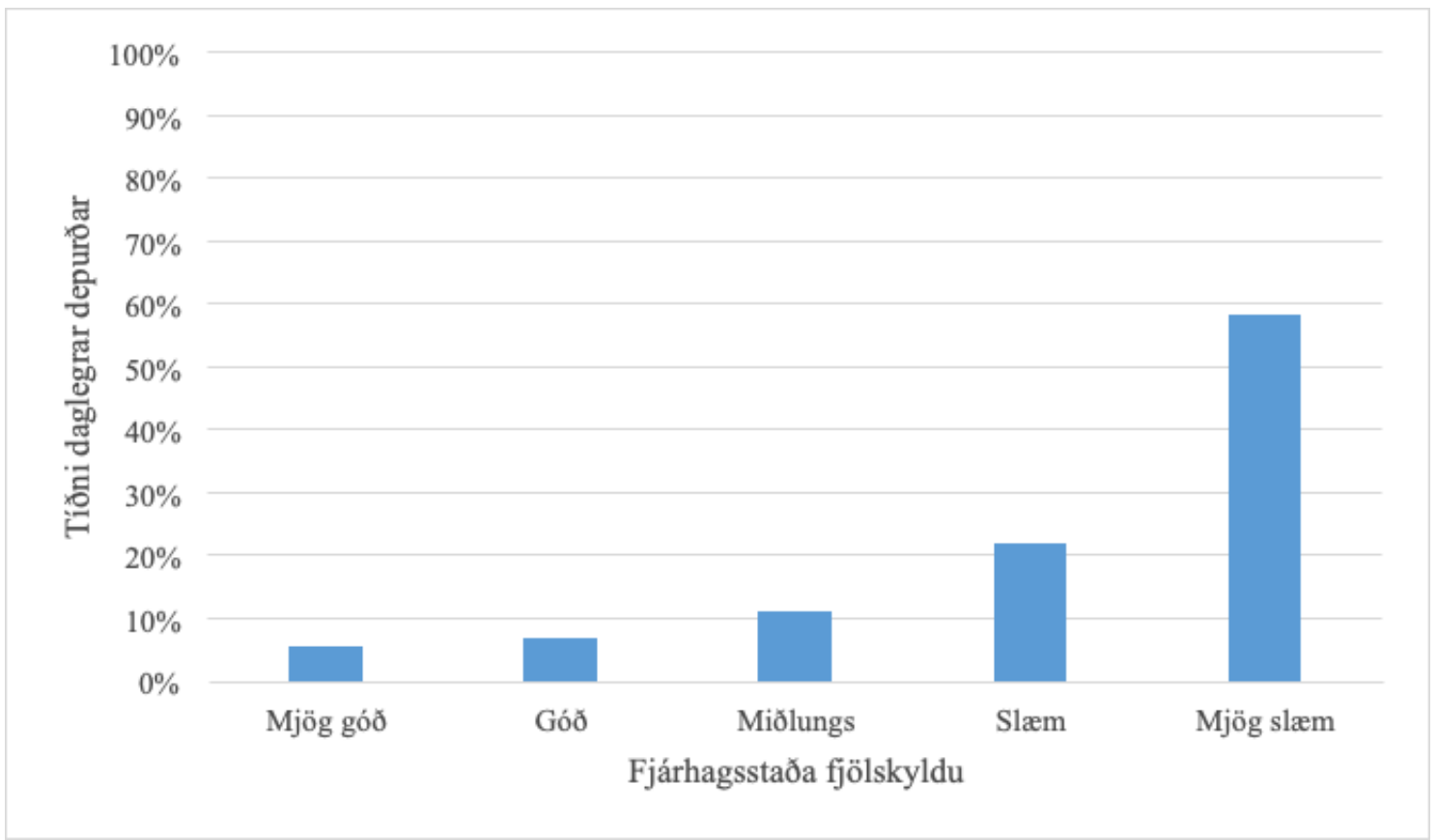

Mynd 1. Hlutfall íslenskra nemenda sem fann daglega fyrir depurð, skipt eftir fjárhagsstöðu fjölskyldu.

Til pess að skoða hvort tengsl væru á milli fæðingarlands unglinga eða foreldra peirra og daglegrar depurðar, var peim skipt upp í prjá flokka: 1) Fæddir á Íslandi líkt og foreldrarnir, 2) Annað hvort fæddir á Íslandi en báðir foreldrarnir voru erlendir eða voru fæddir erlendis og annað foreldrið var íslenskt, og 3) fæddir erlendis og báðir foreldrarnir sömuleiðis. Eins og sést 1 töflu 2 er greinilegt að fæðingarland hefur fylgni við tíðni daglegrar depurðar á meðal unglinga. Hún er tíðust í öllum aldurshópum á meðal peirra unglinga sem eru fæddir erlendis og eiga foreldra sem báðir eru erlendir. Breytingin eftir aldri er hins vegar pveröfug við pað sem gerist á meðal íslensku unglinganna.

Tafla 2. Tengsl daglegrar depurðar á meðal nemenda í 6., 8. og 10. bekk við fæðingarland peirra eða foreldra, hlutfall (fjöldi)

\begin{tabular}{lccc}
\hline & \multicolumn{3}{c}{ Finnur daglega fyrir depurð } \\
\cline { 2 - 4 } & 6. bekkur & 8. bekkur & 10. bekkur \\
\cline { 2 - 4 } Íslenskir foreldrar & $5,4 \%(99)$ & $6,7 \%(140)$ & $8,8 \%(156)$ \\
Annað foreldri erlent eða unglingur fæddur á Íslandi & $8,6 \%(29)$ & $8,8 \%(28)$ & $9,7 \%(30)$ \\
Unglingur og báðir foreldrar fæddir erlendis & $18,8 \%(16)$ & $14,9 \%(14)$ & $12,6 \%(14)$ \\
\hline
\end{tabular}

Mynd 2 sýnir tengsl tíðni daglegrar depurðar við pað hvort nemendur hafi orðið fyrir einelti síðastliðna tvo mánuði. Eins og sjá má er skýrt samband á milli pessara breyta. Af peim sem aldrei hafa verið lagðir í einelti segjast 5,6\% hafa fundið fyrir depurð daglega. Fyrir pá sem hafa verið lagðir í einelti oft í viku er hlutfallið hins vegar 35,9\%. 


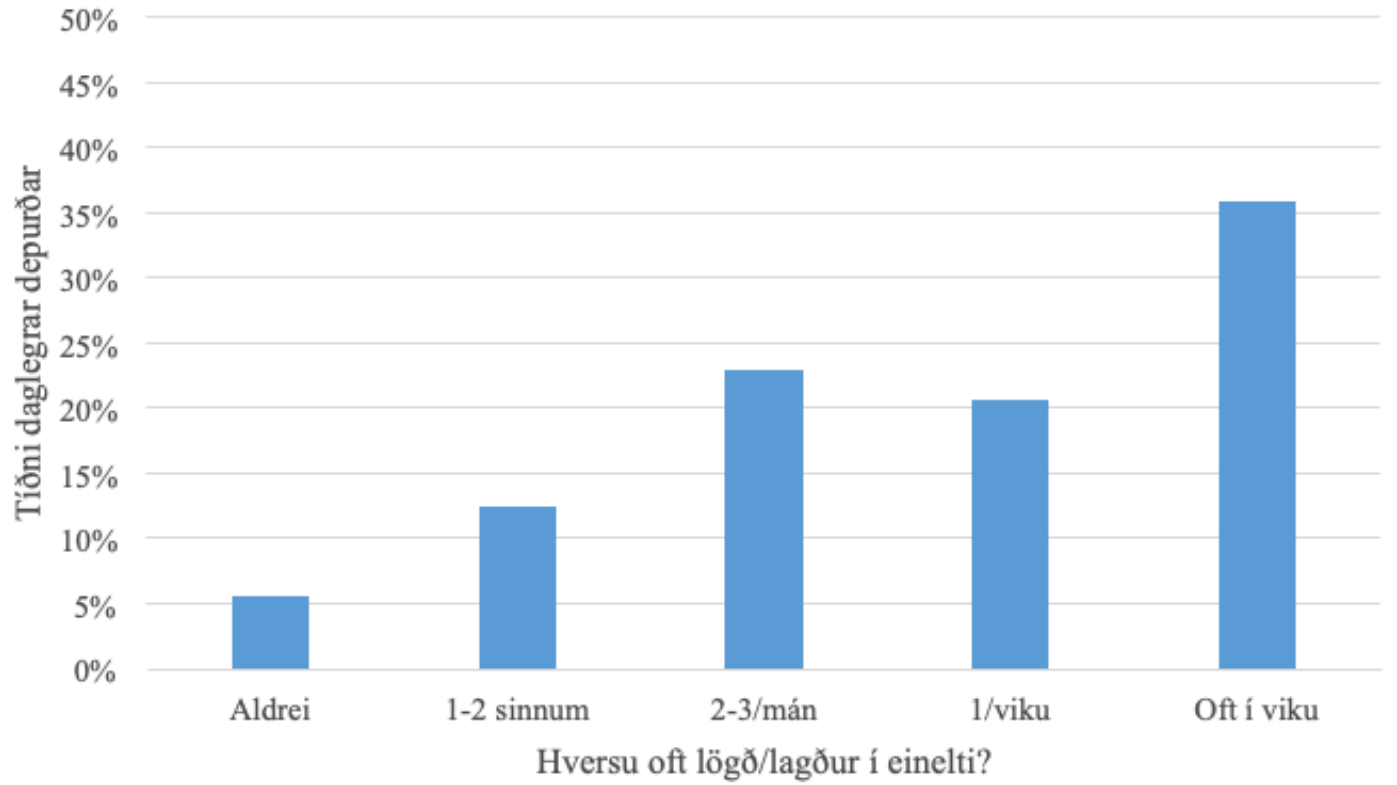

Mynd 2. Tengsl daglegrar depurðar við einelti á síðastliðnum tveimur mánuðum.

Mynd 3 sýnir tengslin á milli daglegrar depurðar og pess hvernig unglingarnir mátu eigið holdafar. Deir sem sögðust vera ,alltof feitir“ voru langlíklegastir til að upplifa daglega depurð, en par á eftir komu peir sem sögðust „alltof grannir“. Ólíkt pví sem búast hefði mátt við var ekki merkjanlegur kynjamunur í pessari mælingu, p.e.a.s. pað að vera of pungur jók líkurnar á depurð en gerði pað ekki meira hjá stelpum en hjá strákum.

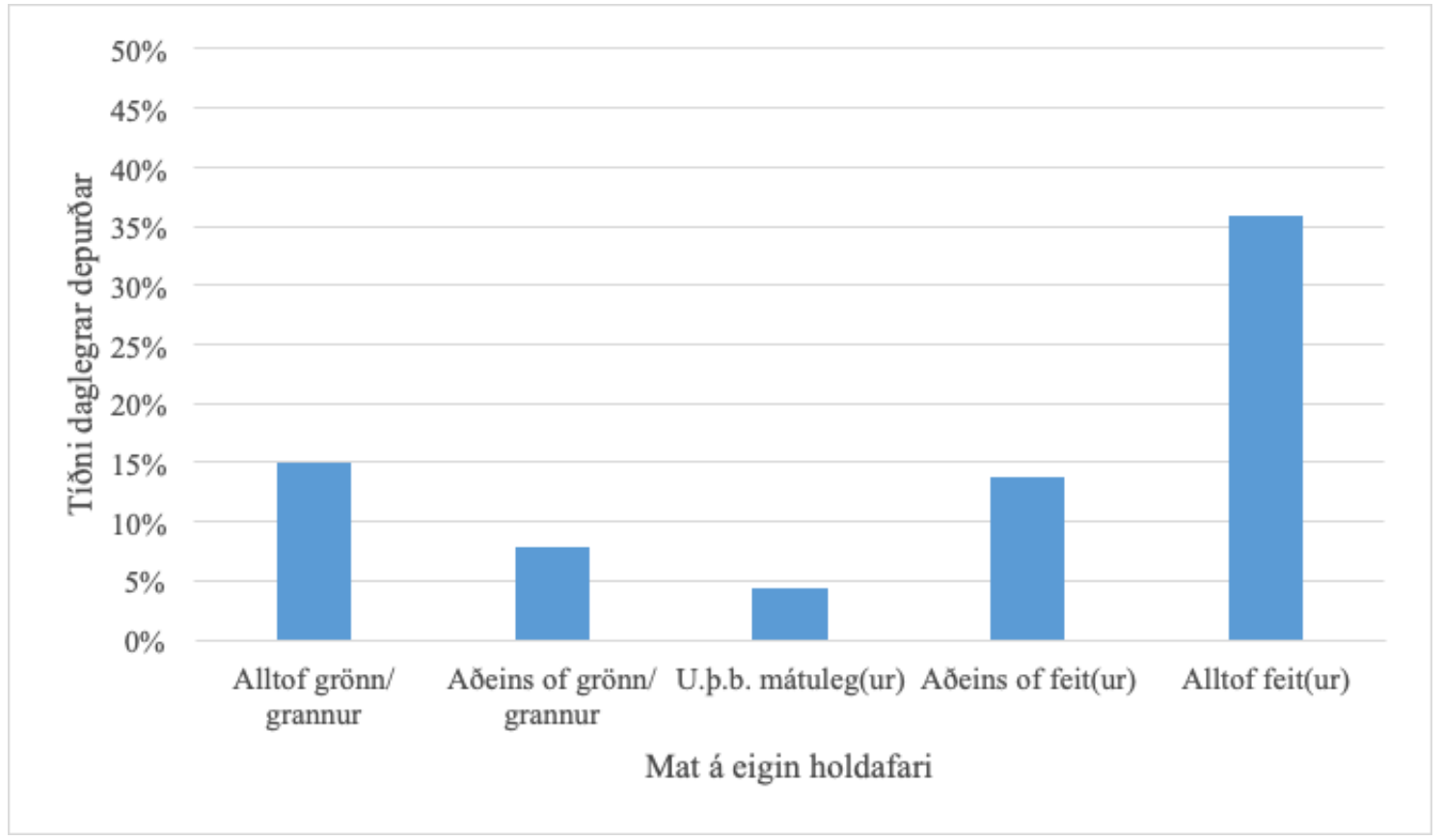

Mynd 3. Tengsl daglegrar depurðar við mat á eigin holdafari. 
Unglingar í 10. bekk voru spurðir hvort peir hefðu einhvern tíma haft samfarir. Tafla 3 sýnir að tengsl eru á milli kynlífsvirkni unglinga og daglegrar depurðar. Strákar sem hafa sofið hjá stelpu eru líklegri til að finna fyrir depurð en hinir sem aldrei hafa prófað og stelpur sem hafa sofið hjá strák eru tvöfalt líklegri til að finna fyrir depurð en hinar sem aldrei hafa gert pað. Unglingar sem hafa átt samkynhneigð kynmök eru síðan enn líklegri til að finna fyrir depurð en jafnaldrar peirra. Unglingar sem flokka sig ekki eftir tvíkosta kynjaskilgreiningu eru líklegri til að vera daprir daglega og sú depurð er meiri á meðal peirra sem hafa stundað kynlíf. Dessar tölur parf pó að túlka með varfærni, par sem fjöldinn sem liggur bak við hverja hlutfallstölu er rýr.

Tafla 3. Tengsl kynlífsvirkni unglinga í 10. bekk við daglega depurð, hlutfall (fjöldi)

\begin{tabular}{lccc}
\hline & Aldrei & $\begin{array}{c}\text { Haft samfarir? } \\
\text { Já, með strák }\end{array}$ & Já, með stelpu \\
\hline Finnur daglega fyrir depurð & & & \\
Strákar & $4,5 \%(34)$ & $29,2 \%(7)$ & $7,2 \%(156)$ \\
Stelpur & $9,4 \%(77)$ & $19,0 \%(47)$ & $27,3 \%(3)$ \\
Annað & $11,8 \%(2)$ & $20,2 \%(2)$ & $62,5 \%(5)$ \\
\hline
\end{tabular}

Tafla 4 sýnir samspil notkunar á tóbaki, áfengi og kannabis við tíðni daglegrar depurðar á meðal nemenda í 10. bekk. Mjög sterk tengsl sáust á milli notkunar allra pessara efna og tíðni daglegrar depurðar. Deir sem höfðu prófað eitthvert peirra voru yfirleitt prefalt líklegri til að finna fyrir depurð daglega en hinir sem aldrei höfðu prófað. Alls segjast 7,4\% nemenda sem aldrei hafa prófað kannabis finna daglega fyrir depurð en sambærilegt hlutfall á meðal peirra sem einhvern tíma segjast hafa notað slík efni er 26,2\%.

Tafla 4. Tengsl daglegrar depurðar unglinga í 10. bekk við reynslu peirra af áfengi, tóbaki og kannabis, hlutfall (fjöldi)

\begin{tabular}{llcc}
\hline & & \multicolumn{2}{c}{ Finnur fyrir depurð daglega } \\
Hefur pú einhvern tíma prófað... & & Nei & Já \\
\cline { 3 - 4 } & Sígarettur & $7,0 \%(131)$ & $22,0 \%(63)$ \\
& Rafrettur & $5,4 \%(75)$ & $15,7 \%(119)$ \\
& Áfengi & $5,7 \%(86)$ & $17,1 \%(107)$ \\
& Kannabis & $7,4 \%(145)$ & $26,2 \%(48)$ \\
\hline
\end{tabular}

Í töflu 5 sést fylgni óeðlilega mikillar notkunar skjátækja við daglega depurð. Dagleg depurð er í öllum tilfellum tíðari á meðal unglinga sem svara fullyrðingunum játandi. Í sumum tilfellum er munurinn talsverður, t.d. par sem spurt er um hvort unglingarnir noti samfélagsmiðla til að komast hjá neikvæðum tilfinningum. Í öðrum er hann mun minni, t.d. par sem spurt er hvort peir hafi vanrækt annað. Til pess að svörun unglinganna teldist vera til merkis um óeðlilega notkun samfélagsmiðla urðu peir að svara fimm af níu fullyrðingum játandi. Af peim sem flokkuðust pannig upplifðu 15,2\% peirra depurð daglega samanborið við 6,8\% peirra sem sýndu af sér óeðlilega skjánotkun. 
Tafla 5. Tengsl daglegrar depurðar unglinga við óeðlilega skjánotkun, hlutfall (fjöldi)

Nei Já

Hefur pú á síðastliðnu ári oft...

...ekki getað hugsað um annað en hvenær pú gætir næst notað 6,9\% (368) 10,3\% samfélagsmiðla

...verið óánægð/ur pví pú vildir geta eytt meiri tíma á 6,6\% (361) 13,4\% (271) samfélagsmiðlum

...reynt að eyða minni tíma á samfélagsmiðlum án pess að takast pað 6,5\% (291) 9,5\% (172)

...vanrækt annað (t.d. tómstundir, ípróttir) vegna pess að pú vildir 7,1\% (412) 11,9\% (54)

komast á samfélagsmiðla

...rifist við aðra vegna notkunar pinnar á samfélagsmiðlum

$6,5 \%(352) \quad 12,9 \%(112)$

....logið að foreldrum pínum eða vinum um pað hversu miklum tíma

$6,6 \%(362) \quad 13,3 \%(103)$

pú eyðir á samfélagsmiðlum

...notað samfélagsmiðla til að komast hjá neikvæðum tilfinningum $\quad 5,6 \%(285) \quad$ 15,1\% (178)

...rifist harkalega við foreldra pína eða systkini vegna notkunar 6,6\% (378) $\quad$ 16,5\% (85)

pinnar á samfélagsmiðlum

...liðið illa pegar pú gast ekki notað samfélagsmiðla

$6,8 \%(376) \quad 12,2 \%(91)$

Í töflu 6 sést hvernig svefnörðugleikar tengjast depurð unglinga. Á meðal peirra sem eiga sjaldan í slíkum erfiðleikum, mælist dagleg depurð aðeins 2,5\% og 81,0\% finnur mjög sjaldan fyrir henni. Á meðal peirra sem eiga oft í svefnörðugleikum mælist dagleg depurð hins vegar 15,9\% eða rúmlega sex sinnum oftar. Degar niðurstöður rannsóknarinnar 2017-2018 voru bornar saman við niðurstöður rannsóknarinnar 2005-2006, kom í ljós að nokkur aukning hafði orðið á svefnörðugleikum. Í fyrri rannsókninni sögðust 9,0\% eiga erfitt með að sofna nánast á hverri nóttu en 49,4\% sögðust sjaldan eða aldrei eiga í slíku. Í síðari rannsókninni voru hlutföllin 11,2\% og $42,4 \%$.

Tafla 6. Tengsl depurðar unglinga við svefnörðugleika, hlutfall (fjöldi)

\begin{tabular}{|c|c|c|}
\hline \multirow[b]{3}{*}{ Finnur fyrir depurð } & \multicolumn{2}{|c|}{ Áttu erfitt með að sofna vikulega eða oftar? } \\
\hline & Nei & Já \\
\hline & & \\
\hline daglega & $2,5 \%(110)$ & $15,9 \%(411)$ \\
\hline vikulega eða oft í viku & $16,4 \%(711)$ & $40,8 \%(1.055)$ \\
\hline mánaðarlega eða sjaldnar & $81,0 \%(3.509)$ & $43,3 \%(1.121)$ \\
\hline
\end{tabular}

Tafla 7 sýnir hvernig tengsl unglinga við foreldra, skóla og vini hefur fylgni við tíðni depurðar. Í henni sést m.a. að tíðni daglegrar depurðar á meðal peirra unglinga sem eru í mjög góðum tengslum við foreldra er 4,2\%, samanborið við 18,3\% á meðal peirra sem telja pau tengsl slök. Fylgnin við skólatengsl eru mjög ápekk foreldratengslunum, en vinatengslin ráða aðeins minna. 
Tafla 7. Tengsl depurðar við félagstengsl unglinga, hlutfall (fjöldi)

\begin{tabular}{lccc}
\hline Tíðni depurðar & & & \\
& & & \\
Tengsl við foreldra eru daglega & Vikulega eða oft í viku & Mánaðarlega eða sjaldnar \\
\cline { 2 - 4 } & & & \\
slök & $18,3 \%(223)$ & $40,4 \%(493)$ & $41,3 \%(504)$ \\
góð & $7,1 \%(138)$ & $30,4 \%(588)$ & $62,5 \%(1.208)$ \\
mjög góð & $4,2 \%(157)$ & $18,1 \%(672)$ & $77,7 \%(2.881)$ \\
Tengsl við skólann eru & & & \\
$\quad$ slök & $16,7 \%(248)$ & $35,4 \%(527)$ & $47,9 \%(713)$ \\
góð & $7,0 \%(129)$ & $28,9 \%(530)$ & $64,1 \%(1.175)$ \\
mjög góð & $4,1 \%(149)$ & $19,7 \%(716)$ & $76,2 \%(2.762)$ \\
Tengsl við vini eru & & & \\
slök & $13,1 \%(235)$ & $30,3 \%(544)$ & $56,6 \%(1.018)$ \\
$\quad$ góð & $6,6 \%(152)$ & $29,1 \%(671)$ & $64,3 \%(1.485)$ \\
mjög góð & $4,8 \%(130)$ & $19,4 \%(529)$ & $75,8 \%(2.062)$ \\
\hline
\end{tabular}

Einnig var skoðað hvernig mismunandi samsetningar slakra félagstengsla gæetu haft fylgni við daglega depurð unglinga. Dar kom í ljós að hjá peim sem höfðu engin slök tengsl var tíðni daglegrar depurðar 3,0\% ( $N=112)$. Dar sem ein tengsl töldust slök var tíðnin 8,9\% ( $N=192)$, en 17,8\% (N=152) ef um tvenns konar slök tengsl var að ræða. Á meðal peirra unglinga sem töldu að öll félagstengsl sín væru slök, var tíðni daglegrar depurðar 33,2\% ( $\mathrm{N}=70)$.

Tafla 8 sýnir niðurstöđur lógistískrar aðhvarfsgreiningar á pví áhættuhlutfalli sem er á að unglingar upplifi daglega depurð út frá pví hvernig peir svara öðrum spurningum. Eins og sést á einbreytugreiningu voru stelpur tvöfalt líklegri en strákar til pess $(p<0,001)$ en nemendur sem skilgreindu sig sem „Annad“ voru átta sinnum líklegri $(\mathrm{p}<0,001)$. Ekki var marktækur munur í áhættuhlutfalli milli 6. og 8. bekkjar en nemendur í 10. bekk voru um helmingi líklegri til að finna fyrir depurð daglega $(\mathrm{p}<0,005)$. Fjárhagsstaða fjölskyldunnar hafði mjög afgerandi fylgni við hættuna á daglegri depurð. Peir sem töldu hana mjög slæma voru 25-falt líklegri til að finna fyrir slíku heldur en hinir sem sögðu að hana mjög góða ( $\mathrm{p}<0,001)$.

Fæðingarland unglingsins og foreldra hans hafði marktæka fylgni við tíðni daglegrar depurðar. Í peim hópi par sem annað foreldri var erlent eða báđir foreldrarnir voru erlendir en unglingur sjálfur var fæddur á Íslandi var áhættuhlutfallið priðjungi hærra en meðal innfæddra Íslendinga $(\mathrm{p}<0,05)$. Ef hins vegar bæði unglingurinn og báðir foreldrarnir voru fæddir erlendis var pað hins vegar rúmlega tvöfalt hærra $(\mathrm{p}<0,001)$.

Greinilegt er að mat unglinga á eigin holdafari réði miklu um áhættuhlutfall fyrir daglega depurð. Detta kom sterkt fram jafnvel hjá peim sem töldu sig vera aðeins of granna $(p<0,001)$. Deir sem sögðust alltof grannir eða aðeins of feitir voru fjórfalt líklegri til að finna fyrir daglegri depurð $(\mathrm{p}<0,001)$ en meðal peirra sem sögðust alltof feitir voru líkurnar tæplega 13-faldar $(\mathrm{p}<0,001)$.

Marktækur munur var á líkum peirra unglinga sem mátu tengsl sín við foreldra sína vera góð og hinna sem töldu pau vera mjög góð ( $\mathrm{p}<0,001)$. Deir sem voru í slökum tengslum við foreldra voru hins vegar langtum líklegri til að upplifa daglega depurð ( $\mathrm{p}<0,001)$. Unglingar sem sögðu að tengsl sín við skólann væru góð voru í marktækt meiri áhættu á að finna fyrir depurð daglega heldur en peir sem sögðu að pau væru mjög góð ( $p<0,001)$. Hinir, sem töldu pau slök, voru svo í enn meiri áhættu fyrir depurð ( $\mathrm{p}<0,001)$. Unglingar sem mátu vinatengsl sín góð voru um 40\% líklegri til að finna fyrir daglegri depurð en hinir sem töldu að pau væru mjög góð ( $p<0,01)$. Deir sem áttu í slökum tengslum við vini voru prefalt líklegri til að upplifa depurð ( $p<0,001$ ). 
Áhugavert er að sjá hve hið minnsta fikt með rafrettur tengist tvöföldun áhættuhlutfalls daglegrar depurðar $(p<0,01)$. Regluleg notkun rafretta (oftar en 30 sinnum yfir ævina) jók áhættuna á daglegri depurð fjór- til fimmfalt $(\mathrm{p}<0,001)$. Fylgnin við sígarettureykingar var jafnvel enn sterkari. Мiðað við pá sem aldrei höfðu reykt voru peir sem höfðu gert pað 30 sinnum eða oftar átta sinnum líklegri til að finna fyrir depurð nær daglega $(\mathrm{p}<0,001)$. Minnsta fikt með áfengi tvöfaldaði líkur á daglegri depurð ( $p<0,001)$ og peir sem höfðu drukkið 30 sinnum eða oftar yfir ævina voru í tífaldri hættu ( $\mathrm{p}<0,001)$. Svipaða sögu var að segja um kannabisneyslu par sem peir sem notað höfðu efnið 30 sinnum eða oftar voru í átta sinnum meiri hættu að upplifa daglega depurð ( $\mathrm{p}<0,001)$. Peir unglingar sem sýndu af sér óeðlilega skjánotkun voru um $60 \%$ líklegri til að upplifa daglega depurð en aðrir jafnaldrar peirra $(p<0,001)$.

Að hafa orðið fyrir einelti einungis einu sinni eða tvisvar síðastliðna tvo mánuði tvöfaldar líkurnar á pví að finna daglega fyrir depurð $(\mathrm{p}<0,001)$ og hafi pað viðgengist oft í viku eru líkurnar á depurð rúmlega nífalt hærri en peirra sem aldrei hafa orðið fyrir einelti $(\mathrm{p}<0,001)$.

Tíðni svefnörðugleika hafði sterka fylgni við hættuna á að unglingar upplifðu depurð daglega (tafla 8). Miðað við pá sem sjaldan eða aldrei áttu í erfiðleikum með svefn, voru peir sem fundu fyrir svefnörðugleikum mánaðarlega í um helmingi meiri hættu á daglegri depurð ( $p<0,05)$, vikulegir örðugleikar prefölduðu hættuna $(\mathrm{p}<0,001)$, oft 1 viku fimmfaldaði hana og peir unglingar sem áttu í erfiðleikum með svefn á svo til hverri nóttu voru í um pað bil 24-faldri áhættu á daglegri depurð.

Tafla 8. Áhættuhlutfall daglegrar depurðar, ásamt fjölda (N) og hlutfalli (\%).

\begin{tabular}{llccc}
\hline Breytur & & Fjöldi & Prósentur & Áhættuhlutfall (95\% C.I.) \\
\hline Kyn & & & \\
& Strákur & 3.398 & $48,9 \%$ & 1,00 \\
& Stelpa & 3.438 & $49,5 \%$ & $2,03(1,68-2,47) \dagger$ \\
& Annað & 107 & $1,5 \%$ & $8,26(5,31-12,84) \dagger$ \\
\hline Bekkur & & & \\
& 6. & 2.256 & $32,5 \%$ & 1,00 \\
& 8. & 2.494 & $35,9 \%$ & $1,16(0,92-1,45)$ \\
& 10. & 2.201 & $31,7 \%$ & $1,47(1,17-1,83) \dagger$ \\
\hline Fjárhagsstaða fjölskyldunnar & & & 1,00 \\
& Mjög góð & 2.806 & $41,0 \%$ & $1,28(1,03-1,60) \star$ \\
& Góð & 2.755 & $40,2 \%$ & $2,19(1,71-2,80) \dagger$ \\
& Miðlungs & 1.131 & $16,5 \%$ & $4,93(3,10-7,86) \dagger$ \\
& Slæm & 118 & $1,7 \%$ & 1,00 \\
& Mjög slæm & 41 & $0,6 \%$ & $24,65(12,97-46,86) \dagger$ \\
\hline Fæðingarland unglings og/eða foreldra & & & $1,33(1,04-1,69) \star$ \\
& Ísland & 5.620 & $82,0 \%$ & $2,40(1,71-3,36) \dagger$ \\
Annað foreldri/ ungl. á Íslandi & 948 & $13,8 \%$ &
\end{tabular}


Tafla 8. Áhættuhlutfall daglegrar depurðar, ásamt fjölda (N) og hlutfalli (\%).

\begin{tabular}{|c|c|c|c|}
\hline Breytur & Fjöldi & Prósentur & Áhættuhlutfall (95\% C.I.) \\
\hline \multicolumn{4}{|l|}{ Mat á eigin holdafari } \\
\hline Mátuleg & 4.583 & $66,4 \%$ & 1,00 \\
\hline Aðeins of grönn & 148 & $2,1 \%$ & $1,89(1,39-2,57) \dagger$ \\
\hline Alltof grönn & 721 & $10,4 \%$ & $3,91(2,43-6,28) \dagger$ \\
\hline Aðeins of feit & 1.242 & $18,0 \%$ & $3,60(2,90-4,46) \dagger$ \\
\hline Alltof feit & 212 & $3,1 \%$ & $12,51(9,13-17,14) \dagger$ \\
\hline \multicolumn{4}{|l|}{ Tengsl við foreldra } \\
\hline Mjög góð & 3.710 & $54,1 \%$ & 1,00 \\
\hline Góð & 1.934 & $28,2 \%$ & $1,74(1,37-2,20) \dagger$ \\
\hline Slök & 1.220 & $17,8 \%$ & $5,06(4,08-6,28) \dagger$ \\
\hline \multicolumn{4}{|l|}{ Tengsl við skóla } \\
\hline Mjög góð & 3.627 & $52,2 \%$ & 1,00 \\
\hline Gód & 1.834 & $26,4 \%$ & $1,77(1,39-2,25) \dagger$ \\
\hline Slök & 1.488 & $21,4 \%$ & $4,67(3,78-5,78) \dagger$ \\
\hline \multicolumn{4}{|l|}{ Tengsl við vini } \\
\hline Mjög góð & 2.721 & $39,9 \%$ & 1,00 \\
\hline Gód & 2.308 & $33,8 \%$ & $1,41(1,10-1,79) \dagger$ \\
\hline Slök & 1.797 & $26,3 \%$ & $3,00(2,40-3,75) \dagger$ \\
\hline \multicolumn{4}{|l|}{ Rafrettur um ævina } \\
\hline Aldrei & 1.392 & $64,7 \%$ & 1,00 \\
\hline 1-2 sinnum & 201 & $9,3 \%$ & $2,05(1,23-3,41) \dagger$ \\
\hline 3-5 sinnum & 96 & $4,5 \%$ & $2,04(1,02-4,09)$ * \\
\hline 6-9 sinnum & 62 & $2,9 \%$ & $3,38(1,65-6,91) \dagger$ \\
\hline 10-19 sinnum & 50 & $2,3 \%$ & $2,86(1,24-6,57) \star$ \\
\hline 20-29 sinnum & 24 & $1,1 \%$ & $4,62(1,68-12,72) \dagger$ \\
\hline $30+$ & 326 & $15,2 \%$ & $4,46(3,12-6,37) \dagger$ \\
\hline \multicolumn{4}{|l|}{ Sígarettur um ævina } \\
\hline Aldrei & 6.369 & $93,6 \%$ & 1,00 \\
\hline 1-2 sinnum & 169 & $2,5 \%$ & $3,00(1,98-4,52) \dagger$ \\
\hline 3-5 sinnum & 52 & $0,8 \%$ & $2,25(1,01-5,02) \star$ \\
\hline 6-9 sinnum & 36 & $0,5 \%$ & $4,82(2,25-10,32) \dagger$ \\
\hline 10-19 sinnum & 28 & $0,4 \%$ & $3,14(1,19-8,31) \star$ \\
\hline 20-29 sinnum & 11 & $0,2 \%$ & $5,42(1,43-20,51)$ * \\
\hline $30+$ & 137 & $2,0 \%$ & $7,80(5,41-11,23) \dagger$ \\
\hline
\end{tabular}


Tafla 8. Áhættuhlutfall daglegrar depurðar, ásamt fjölda (N) og hlutfalli (\%).

\begin{tabular}{|c|c|c|c|}
\hline Breytur & Fjöldi & Prósentur & Áhæettuhlutfall (95\% C.I.) \\
\hline \multicolumn{4}{|l|}{ Áfengi um ævina } \\
\hline Aldrei & 5.658 & $83,5 \%$ & 1,00 \\
\hline $1-2$ sinnum & 560 & $8,3 \%$ & $2,17(1,64-2,86) \dagger$ \\
\hline $3-5$ sinnum & 218 & $3,2 \%$ & $2,84(1,93-4,19) \dagger$ \\
\hline 6-9 sinnum & 120 & $1,8 \%$ & $2,81(1,68-14,70) \dagger$ \\
\hline 10-19 sinnum & 87 & $1,3 \%$ & $3,59(2,07-6,25) \dagger$ \\
\hline 20-29 sinnum & 35 & $0,5 \%$ & $5,52(2,57-11,87) \dagger$ \\
\hline $30+$ & 96 & $1,4 \%$ & $9,56(6,24-14,67) \dagger$ \\
\hline \multicolumn{4}{|l|}{ Kannabis um ævina } \\
\hline Aldrei & 1.970 & $91,5 \%$ & 1,00 \\
\hline $1-2$ sinnum & 60 & $2,8 \%$ & $4,20(2,28-7,71) \dagger$ \\
\hline 3-5 sinnum & 36 & $1,7 \%$ & $2,52(1,03-6,15) \star$ \\
\hline 6-9 sinnum & 13 & $0,6 \%$ & $3,78(1,03-13,87)$ * \\
\hline 10-19 sinnum & 14 & $0,7 \%$ & $2,10(0,47-9,46)$ \\
\hline $20-29$ sinnum & 12 & $0,6 \%$ & $4,20(1,12-15,67)$ * \\
\hline $30+$ & 48 & $2,2 \%$ & $8,25(4,51-15,07) \dagger$ \\
\hline \multicolumn{4}{|l|}{ Óeðlileg skjánotkun } \\
\hline Nei & 5.904 & $92,6 \%$ & 1,00 \\
\hline Já & 473 & $7,4 \%$ & $1,59(1,47-1,69) \dagger$ \\
\hline \multicolumn{4}{|l|}{ Einelti síðastliðna tvo mánuði } \\
\hline Aldrei & 5.797 & $84,4 \%$ & 1,00 \\
\hline $1-2$ sinnum & 648 & $9,4 \%$ & $2,42(1,87-3,14) \dagger$ \\
\hline $3-6$ sinnum & 153 & $2,2 \%$ & $5,03(3,39-7,45) \dagger$ \\
\hline Vikulega & 111 & $1,6 \%$ & $4,43(2,76-7,11) \dagger$ \\
\hline Oftar & 156 & $2,3 \%$ & $9,49(6,72-13,41) \dagger$ \\
\hline \multicolumn{4}{|l|}{ Svefnörðugleikar } \\
\hline Aldrei & 2.941 & $42,5 \%$ & 1,00 \\
\hline Mánaðarlega & 1.389 & $20,1 \%$ & $1,54(1,05-2,26) \star$ \\
\hline Vikulega & 953 & $13,8 \%$ & $3,00(2,07-4,26) \dagger$ \\
\hline Oft í viku & 870 & $12,6 \%$ & $5,00(3,59-7,00) \dagger$ \\
\hline Daglega & 764 & $11,0 \%$ & $23,87(17,88-31,87) \dagger$ \\
\hline
\end{tabular}

$\star \mathrm{p}<0,05+\mathrm{p}<0,01$ 


\section{Umræða}

Nýgengi depurðar nær hámarki á unglingsárunum og getur leitt til virkniskerðingar bæði í bráð og lengd (Costello, Mustillo, Erkanli, Keeler og Angold, 2003). Jafnvel pegar depurð ungmenna nær að próast yfir í klínískt punglyndi er stór hluti peirra vangreindur og ómeðhöndlaður (Cairns, Yap, Reavley og Jorm, 2015). Dví miður eru ennfremur líkur til pess að pó svo að greining og meðferð myndu stóreflast yrði aðeins hægt að draga að hluta til úr sjúkdómsbyrðinni með bestu fáanlegri heilbrigðispjónustu (Andrews, Issakidis, Sanderson, Corry og Lapsley, 2004). Aðgerðir sem miða að pví að koma í veg fyrir að depurð próist á unglingsárum hafa pví skiljanlega fengið verðskuldaða athygli á síðustu árum (Cairns o.fl., 2015).

Í pessari rannsókn kom í ljós að mjög slæm fjárhagsstaða fjölskyldunnar og svefnörðugleikar á hverri nóttu 25-földuðu líkurnar á pví að unglingar fyndu fyrir depurð á hverjum degi. Að finnast maður vera alltof feitur 13-faldaði líkurnar, tíð áfengisneysla tífaldaði pær og einelti oft í viku nífaldaði pær. Peir unglingar sem skilgreindu kyn sitt sem „Annað“ en strákur eða stelpa, voru átta sinnum líklegri en jafnaldrar peirra til að finna fyrir depurð daglega. Sama átti við um pá sem reyktu sígarettur eða kannabis reglulega. Fimmföldun á áhættu sást meðal peirra sem notuðu rafrettur reglulega, áttu slök tengsl við foreldra eða við skóla. Slök vinatengsl prefölduðu líkurnar. Aðrir pættir sem um pað bil tvöfölduðu líkurnar voru fæðingarland unglings og foreldra hans. Stelpur voru líka tvöfalt líklegri en strákar til að finna fyrir depurð nær daglega. Enn aðrir pættir höfðu veikari fylgni. Pannig voru 10. bekkingar helmingi líklegri en 6 . bekkingar að finna fyrir depurð daglega og óeðlileg skjánotkun jók líkurnar um 60\%.

Safngreining á peim breytingum sem orðið hafa á geðheilsu unglinga og tók til 19 rannsókna i 12 löndum, benti til pess að henni hefði einkum farið hrakandi á meðal stúlkna (Bor o.fl., 2014). Detta er í samræmi við niðurstöður Rannsókna og greiningar hér á landi (Margrét Lilja Guðmundsdóttir o.fl., 2016). Dær niðurstöður sem hér eru kynntar sýna að pó tíðni daglegrar depurðar sé miklu algengari á meðal stúlkna, pá hefur aukningin á henni á árabilinu 2006 til 2018 dreifst jafnt á milli kynja. Ýmsir mögulegir orsakapættir hafa verið nefndir til sögunnar til að skýra hærri tíðni depurðar meðal stúlkna. West og Sweeting, (2003) töldu að áhyggjur tengdar námi og útliti réðu par mestu og víst er að aðrar rannsóknir (Wiklund, MalmgrenOlsson, Ohman, Bergstrom og Fjellman-Wiklund, 2012), par á meðal á Íslandi (Inchley o.fl., 2016), hafa sýnt að stelpur upplifa meira álag vegna skólanáms en strákar. Einnig kann að vera að sú staðreynd að stelpur verða fyrr kynproska geri pær útsettari fyrir geðlægðum (Crockett, Carlo, Wolff og Hope, 2013). Dar kunna að spila inn í hormónabreytingar en ekki síður sú samfélagslega kynvæðing sem getur fylgt (Hatch, 2011). Pá hefur verið bent á neikvæð áhrif samfélagsmiðla og neytendamenningar á sjálfsmynd ungra kvenna (Booker, Kelly og Sacker, 2018). Sumir fræðimenn hafa haldið pví fram að stelpur séu næmari fyrir félagslegu umhverfi og tilfinningalegum upplifunum en strákar og að pær staldri lengur við neikvæðar hugsanir (Rubenstein o.fl., 2015).

Rannsóknir sýna að strákar í 7. og 8. bekk eru mun ólíklegri en stelpur til að sýna depurð út á við, enda kann pað að vera mun afdrifaríkara fyrir stráka en stelpur. Deir strákar sem sýna depurð á annað borð eru gjarnan hunsaðir af jafnöldrum sínum og lenda í ýmiss konar félagslegum erfiðleikum. Hins vegar veldur pað ekki félagslegri útskúfun pó stelpur sýni merki depurðar (Perry-Parrish og Zeman, 2011).

Mjög sterk fylgni kom fram á milli svefnörðugleika og depurðar, sem hefur einnig komið skýrt fram í öðrum rannsóknum (Conklin o.fl., 2018; Roberts o.fl., 2009). Af peim sem áttu í svefnörðugleikum sjaldnar en einu sinni í viku sögðust tæplega 3\% finna fyrir depurð daglega, en á meðal peirra sem áttu oftar í vandræðum með svefn var tíðni daglegrar depurðar 16\%. Hlutfall peirra unglinga sem sagðist eiga í svefnörðugleikum næstum pví á hverri nóttu jókst um fjórðung á árabilinu 2006-2018. 
Niðurstöðurnar sýna að tengsl eru á milli kynlífsvirkni unglinga og daglegrar depurðar. Reynsla af gagnkynhneigðu kynlífi hefur sterka fylgni við daglega depurð á meðal stelpna og einnig nokkra fylgni hjá strákum. Reynsla af samkynhneigðum kynmökum hefur enn sterkari fylgni við daglega depurð. Pá er einnig ljóst að unglingar sem ekki flokka sig samkvæmt hefðbundnum tvíkosta kynjaskilgreiningum eru mun líklegri til að finna fyrir depurð daglega. Petta er í samræmi við fyrri rannsóknir (Arnarsson o.fl., 2015; Thorsteinsson, Loi, Sveinbjornsdottir og Arnarsson, 2017) sem sýna að kynhneigð og kynlífsreynsla unglinga hefur mikil áhrif á heilsu peirra og líðan. Mikilvægt er að taka fram að í spurningalistanum 2018 voru unglingarnir ekki spurðir um hvort kynlífsreynsla peirra hefði verið of beldisfull eður ei, en vitað er að 4\% unglinga á pessum aldri hefur verið nauðgað (Ársæll Arnarsson, Kristín Heba Gísladóttir og Stefán Hrafn Jónsson, 2016) og voru stelpur par í meirihluta.

Tengslin á milli depurðar og vímuefnaneyslu unglinga eru vel pekkt. Pau geta gengið í báðar áttir, p.e. vímuefnaneyslan getur orsakað depurð og öfugt. Hvort sem veldur upphaflega skiptir minna máli en sú staðreynd að parna á milli getur myndast vítahringur sífellt meiri neyslu og verri líðunar sem hefur mikil áhrif á framtíðarheilsu (Johannessen, Andersson, Bjorngaard og Pape, 2017). Баð er hins vegar ljóst að jafnvel pó vímuefnaneysla hafi tengsl við depurð á meðal íslenskra unglinga, pá getur hún ekki skýrt aukninguna í depurð, pví verulega hefur dregið úr henni á síðastliðnum árum (Arnarsson, Kristofersson og Bjarnason, 2018).

Tengsl unglinga við foreldra sína hafa mikil áhrif á pað hversu líklegir peir eru til að finna fyrir depurð, sem er í samræmi við erlendar rannsóknir (McGraw, Moore, Fuller og Bates, 2008). Niðurstöðurnar hér að framan sýna að $18 \%$ peirra unglinga sem segjast vera í slökum tengslum við foreldra finna fyrir depurð daglega, samanborið við $4 \%$ peirra sem eru í mjög góðum tengslum. Fyrri rannsóknir hafa hins vegar sýnt að tengsl íslenskra unglinga við foreldra sína hafa batnað á undanförnum árum (Arnarsson, Portebny, Torsheim og Eriksson, í prentun) og pví ljóst að aukningin í depurð á árabilinu 2006-2018 verður ekki skýrð með slakari tengslum við foreldra.

Mat unglinganna á tengslum sínum við skólann hefur greinilega fylgni við tíðni daglegrar depurðar. Á meðan $17 \%$ peirra sem segja pau slök upplifa depurð svo oft, á pað sama við um $4 \%$ nemenda sem segja pau mjög góð. Detta er í samræmi við niðurstöður erlendra rannsókna (McGraw o.fl., 2008). Almennt líður íslenskum unglingum mjög vel í skóla og hefur alls ekki dregið úr peirri vellíðan á síðastliðnum árum. Hins vegar hafa rannsóknir sýnt að álag vegna náms hefur aukist nokkuð hjá íslenskum stúlkum, einkum í 10. bekk (Inchley o.fl., 2016), sem kann að einhverju leyti að skýra aukna depurð sem sést einmitt í pessum hópi.

Góð vinatengsl hafa einnig fylgni við minni tíðni depurðar. Um 5\% unglinga sem segjast eiga í mjög góðum vinatengslum finna fyrir daglegri depurð, samanborið við $13 \%$ peirra sem telja tengsl sín við vini vera slök. Erlendar rannsóknir hafa einnig sýnt fram á pessi tengsl (McGraw o.fl., 2008).

Mikilvægt er að taka pað fram að í pessari grein er ekki stuðst við klíníska greiningu á punglyndi, heldur er um að ræða faraldsfræðilega rannsókn á tíðni daglegrar depurðar. Dað parf pví að fara með gát pegar niðurstöðurnar eru túlkaðar. Í skýrslu frá sænskum heilbrigðisyfirvöldum kom fram að hlutfall barna og unglinga sem meðhöndluð voru vegna kvíða eða bunglyndis hafði aukist mikið á árabilinu 2006-2016 (Socialstyrelsen, 2016). Myndin er pó kannski ekki alveg svona einföld. Kanadísk rannsókn (Wiens o.fl., 2017), sem tók yfir árabilið 2003 til 2014, sýndi til að mynda að pó sífellt fleiri unglingar væru greindir með vægar lyndisraskanir, pá hefði tilfellum alvarlegs punglyndis ekki fjölgað. Höfundarnir nefna að mögulega séu unglingar í dag duglegri við að leita sér hjálpar eða að meðferðaraðilar setji frekar greiningar á pá sem til peirra leita. Hugsanlega má skýra próunina á Íslandi með svipuðum hætti. Pó pað sé vissulega jákvætt að fleiri unglingar leiti sér hjálpar og fái greiningu, pá bendir pað einnig til pess að pær forvarnir og meðferðir sem í boði hafa verið séu ekki að ná tilætluðum árangri. Рað má pví ætla að álagið á geðheilbrigðiskerfið komi til með að aukast á næstu árum. 
Af pversniðsrannsókn eins og hér er á ferðinni verða ekki dregnar skýrar ályktanir um orsakasambönd og augljóst er að í mörgum tilfellum getur dagleg depurð virkað fremur sem frumbreyta en fylgibreyta. Pannig er ljóst að svefnörðugleikar geta orsakað depurð en depurð getur einnig valdið svefnörðugleikum. Slök tengsl við foreldra, vini og skóla geta aukið hættuna á daglegri depurð, en dagleg depurð getur einnig orsakað slök tengsl. Dað sama á við um samfélagsmiðla - mjög mikil notkun peirra tengist daglegri depurð en einnig er ljóst að daprir unglingar sækja frekar í að nota pá mikið.

Dessi rannsókn snertir ekki á tengslum unglinga við atvinnumarkaðinn, sem gæti hugsanlega verið ein af skýringunum á aukinni depurð. Í fyrsta lagi er pað vegna pess að margir eldri unglingar stunda talsverða vinnu með skólanum. Í öðru lagi vegna pess að sá vinnumarkaður sem mætir pessum unglingum í framtíðinni krefst meiri menntunar og hæfni en er á sama tíma óöruggari en sá sem fyrri kynslóðir hafa séð fyrir sér. Dað er pví ekki ólíklegt að sífellt stærri hluti ungmenna upplifi kvíða vegna framtíðarmenntunar og möguleika á vinnumarkaði (Folkhälsomyndigheten, 2018). Hugsanlega skýrist aukin depurð að hluta til af pessum orsökum, en peirri spurningu verður ekki svarað með peim gögnum sem hér liggja til grundvallar.

Nokkrar yfirlitsgreinar hafa sýnt fram á að hægt sé að koma í veg fyrir eða seinka geðlægð meðal unglinga (Christensen, Pallister, Smale, Hickie og Calear, 2010; Horowitz og Garber, 2006; Merry o.fl., 2011; Stice, Shaw, Bohon, Marti og Rohde, 2009). Mikill kostnaður fylgir hins vegar gjarnan inngripum af pessu tagi sem kemur í veg fyrir að peim sé beitt í verulegum mæli yfir lengri tíma. Dað eru vissulega til forvarnaraðgerðir sem hægt er að setja á laggirnar með fremur litlum kostnaði í gegnum netið eða öpp, en mörg styðjast við tímafreka og dýra aðkomu fagaðila. Vegna kostnaðar er peim síðarnefndu oftast beint að einstaklingum sem taldir eru vera í áhættuhóp. Баð krefst skimunar sem getur hvoru tveggja stimplað unglinga en einnig undanskilið stóran hóp sem gæti haft gagn af slíkum aðgerðum. Dví hafa ýmsir fræðimenn lagt til að forvarnir purfi að verða auðframkvæmanlegri, ódýrari og aðgengilegri en nú tíðkast (Cairns o.fl., 2015; Munoz, Beardslee og Leykin, 2012). Leggja parf áherslu á að efla bjargráð, lífsleikni, nærandi samskipti og heilbrigðan lífsstíl unglinga (Cairns o.fl., 2015). Á Íslandi purfa foreldrar að huga vel að svefni barna sinna, skólar að einelti og álagi, stjórnvöld verða að reyna eftir fremsta megni að rétta hlut fátækari fjölskyldna og samfélagið allt að hætta að stimpla unglinga út frá kyni, kynpætti, kynhneigð, holdafari, efnahagslegri stöðu eða hæfni.

Mikilvægt er að hafa í huga að í pessari rannsókn er depurð mæld með svörum nemenda við einni spurningu. Degar slík nálgun er notuð parf að gjalda varhug við innihaldsréttmæti, næmi og áreiðanleika pessarar stöku spurningar. Sýnt hefur verið fram á innihaldsréttmæti og áreiðanleika hennar ((Haugland og Wold, 2001), en næmi stakrar spurningar er augljóslega takmarkað. Nákvæm mæling á geðslagi unglinga krefst mun umfangsmeiri spurningalista sem rúmast ekki innan pessarar rannsóknar par sem reynt er að gefa breiða mynd af heilsu, hegðun og líðan. Hins vegar hefur pessum gögnum verið safnað yfir langt árabil með afar stóru úrtaki nemenda og gefa pau pví augljóslega nokkuð góða mynd af próun mála. Niðurstöðurnar parf að túlka af varfærni.

\section{Sadness amongst school-children in Iceland}

Although it is perfectly normal to experience a low mood every now and then during adolescence as in other periods of the life-span, chronic sadness during this period can be a precursor to serious and repeated bouts of depression, anxiety, substance abuse and suicidal behavior. The current generation of adolescents is generally thought, both by the public as well as professionals, to be more susceptible to sadness than previous generations. How susceptible adolescents are to serious bouts of sadness is related to a number of concurrent factors that have to do with genetics, development and social status. The aim of the current study was to document changes in the prevalence of daily sadness amongst Icelandic adolescents from 2006-2018, and identify factors related to daily sadness in 2018 . 
The study is based on information gathered as part of the project Health Behaviour in School-aged Children (HBSC) in which adolescents are asked about various issues relating to health, well-being and social situation. This data has been collected in Iceland every fourth year from 2006 and in the final phase of 2017-2018 a total of 7,159 students responded to the questionnaire. Prior to data collection, the questionnaire, together with a research plan, was submitted to the Icelandic Data Protection Authority and the University of Iceland Ethics Committee, neither of which had any reservations regarding the procedure. Subsequently, the same information was sent to all headmasters in Iceland in schools that had students in 6th, 8 th or 10th grade, requesting their permission to conduct the study. As a follow-up, all parents and guardians received a letter of introduction with clear instructions as to how to decline a child's participation. In the 2017-2019 phase, the questionnaire was in digitized form. The tables in the school-room were moved apart to ensure that students could not see one another's answers. Then each student accessed the document on their computer. In the beginning there was a short introduction to the study accompanied by a clear statement that even though the study had been approved by school authorities and parents, the students were under no obligation to participate. The anonymity of answers was also emphasized.

The results show that the prevalence of daily sadness had increased by a third from 2006 to 2018, from 5.8\% to 7.6\% respectively. Adolescents coming from the poorest homes and those experiencing sleep difficulties almost every night had an almost 25 -fold risk of daily sadness. Adolescents that experience themselves as being far too fat have a 13-fold risk, using alcohol frequently increased it tenfold and being bullied often every week increased the risk ninefold. Adolescents identifying their sex as "Other" than male or female were eight times more likely to experience daily sadness, as were those who frequently smoked cigarettes or cannabis. A fivefold increase in risk was seen amongst most frequent users of e-cigarettes, as well as among those who had poor relations with parents or school. Poor relations with friends tripled the risk. Other factors that approximately doubled the risk were immigration status, and female compared with male gender. Other variables had less impact. Tenth graders were around $50 \%$ more likely than sixth graders to experience sadness on a daily basis and disordered use of social media caused a $60 \%$ increase.

From these results one can conclude that the prevalence of daily sadness amongst Icelandic adolescents has indeed increased during the period from 2006 to 2018. Various factors influence the likelihood of daily sadness but the increase noted is probably related to upsurge in sleeping difficulties. It is important to make risk prevention easier, cheaper and more accessible to adolescents. Emphasis needs to be placed on coping skills, life skills, nurturing communication and healthy life-styles. In Iceland parents need to pay particular attention to their children's sleeping habits, schools need to focus on reducing bullying and school stress, and society as a whole should stop stigmatizing adolescents based on gender, race, sexual orientation, body composition, economic status or skills.

Key words: Adolescents, sadness, school, parents, peers 


\section{Um höfundinn}

Ársæll Arnarsson (arsaell@hi.is) er prófessor í tómstunda- og félagsmálafræði við Menntavísindasvið Háskóla Íslands. Hann lauk BA-prófi í sálfræði 1993, MS-gráđu í heilbrigðisvísindum 1997 og PhD-grádu í líf- og læknavísindum frá Háskóla Íslands árið 2009. Síðastliðinn áratug hafa rannsóknir hans aðallega beinst að heilsufari og líðan unglinga.

\section{About the author}

Ársæll Arnarsson (arsaell@hi.is) is a professor of leisure studies in the University of Iceland School of Education. He completed a BA degree in psychology in 1993, an MSc degree in Health Sciences in 1997 and a PhD in Biomedical Sciences in 2009 from the University of Iceland. For the past decade his research has focused on the health and well-being of adolescents.

\section{Heimildir}

Andersen, P. L. og Dæhlen, M. (2017). Sosiale relasjoner i ungdomstida - Identifisering og beskrivelse av ungdom med svake relasjoner til foreldre, skole og venner. Oslo: Nova.

Andrews, G., Issakidis, C., Sanderson, K., Corry, J. og Lapsley, H. (2004). Utilising survey data to inform public policy: Comparison of the cost-effectiveness of treatment of ten mental disorders. British Journal of Psychiatry, 184(6), 526-533. doi:10.1192/bjp.184.6.526

Arnarsson, A., Kristofersson, G. K. og Bjarnason, T. (2018). Adolescent alcohol and cannabis use in Iceland 1995-2015. Drug and Alcohol Review, 37(viðauki 1), S49-S57. doi:10.1111/dar.12587

Arnarsson, A., Portebny, T., Torsheim, T. og Eriksson, C. (i prentun). Trends in Nordic adolescents' communication with their parents. Stokkhólmur: Nordic Welfare Research.

Arnarsson, A., Sveinbjornsdottir, S., Thorsteinsson, E. B. og Bjarnason, T. (2015). Suicidal risk and sexual orientation in adolescence: A population-based study in Iceland. Scandinavian Journal of Public Health, 43(5), 497-505. doi:10.1177/1403494815585402

Ársæll Arnarsson, Kristín Heba Gísladóttir og Stefán Hrafn Jónsson (2016). Algengi kynferðislegs áreitis og ofbeldis gegn íslenskum unglingum. Laknablaðið, 102(6), 293-299.

Booker, C. L., Kelly, Y. J. og Sacker, A. (2018). Gender differences in the associations between age trends of social media interaction and well-being among 10-15 year olds in the UK. BMC Public Health, 18. doi:10.1186/ s12889-018-5220-4

Bor, W., Dean, A. J., Najman, J. og Hayatbakhsh, R. (2014). Are child and adolescent mental health problems increasing in the 21 st century? A systematic review. Australian and New Zealand Journal of Psychiatry, 48(7), 606-616. doi:10.1177/0004867414533834

Cairns, K. E., Yap, M. B. H., Reavley, N.J. og Jorm, A. F. (2015). Identifying prevention strategies for adolescents to reduce their risk of depression: A Delphi consensus study. Journal of Affective Disorders, 183, 229-238. doi:10.1016/j.jad.2015.05.019

Carli, V., Hoven, C. W., Wasserman, C., Chiesa, F., Guffanti, G., Sarchiapone, M., . . Wasserman, D. (2014). A newly identified group of adolescents at "invisible" risk for psychopathology and suicidal behavior: Findings from the SEYLE study. World Psychiatry, 13(1), 78-86. doi:10.1002/wps.20088

Christensen, H., Pallister, E., Smale, S., Hickie, I. B. og Calear, A. L. (2010). Community-based prevention programs for anxiety and depression in youth: A systematic review. Journal of Primary Prevention, 31(3), 139-170. doi:10.1007/s10935-010-0214-8

Collishaw, S. (2015). Secular trends in child and adolescent mental health. Annual Research Review, 56(3), 370-393. doi:10.1111/jcpp.12372 
Conklin, A. I., Yao, C. A. og Richardson, C. G. (2018). Chronic sleep deprivation and gender-specific risk of depression in adolescents: A prospective population-based study. BMC Public Health, 18. doi:10.1186/ s12889-018-5656-6

Costello, E. J., Mustillo, S., Erkanli, A., Keeler, G. og Angold, A. (2003). Prevalence and development of psychiatric disorders in childhood and adolescence. Archives of General Psychiatry, 60(8), 837-844. doi:10.1001/ archpsyc.60.8.837

Crockett, L. J., Carlo, G., Wolff, J. M. og Hope, M. O. (2013). The role of pubertal timing and temperamental vulnerability in adolescents' internalizing symptoms. Development and Psychopathology, 25(2), 377-389. doi:10.1017/s0954579412001125

Fatori, D., Bordin, I. A., Curto, B. M. og de Paula, C. S. (2013). Influence of psychosocial risk factors on the trajectory of mental health problems from childhood to adolescence:A longitudinal study. BMC Psychiatry, 13. doi:10.1186/1471-244x-13-31

Fergusson, D. M., Boden, J. M. og Horwood, L. J. (2007). Recurrence of major depression in adolescence and early adulthood, and later mental health, educational and economic outcomes. British Journal of Psychiatry, 191(4), 335-342. doi:10.1192/bjp.bp.107.036079

Folkhälsomyndigheten. (2018). Varför har den psykiska ohälsan ökat bland barn och unga i Sverige? Solna: Höfundur.

Graham, C.A. og Easterbrooks, M.A. (2000). School-aged children's vulnerability to depressive symptomatology:The role of attachment security, maternal depressive symptomatology, and economic risk. Development and Psychopathology, 12(2), 201-213.

Margrét Lilja Guðmundsdóttir, Hrefna Pálsdóttir, Jón Sigfússon, Ingibjörg Eva Pórisdóttir, Erla María Tölgyes, Álfgeir Logi Kristjánsson og Inga Dóra Sigfúsdóttir (2016). Ungt fólk 2016: 8.-10. bekkur. Reykjavík: Rannsóknir og greining og Mennta- og menningarmálaráðuneytið.

Hatch, L. (2011). The American Psychological Association task force on the sexualization of girls: A review, update and commentary. Sexual Addiction \& Compulsivity, 18(4), 195-211. doi:10.1080/10720162.2011. 613326

Haugland, S. og Wold, B. (2001). Subjective health complaints in adolescence - Reliability and validity of survey methods. Journal of Adolescence, 24(5), 611-624. doi:10.1006/jado.2000.0393

Horowitz, J. L. og Garber, J. (2006). The prevention of depressive symptoms in children and adolescents: A meta-analytic review. Journal of Consulting and Clinical Psychology, 74(3), 401-415. doi:10.1037/0022006x.74.3.401

Inchley, J., Currie, D., Young, T., Samdal, O., Torsheim, T., Augustson, L., . . Barnekow,V. (2016). Growing up unequal: gender and socioeconomic differences in young people's health and well-being. Kaupmannahöfn: World Health Organization.

Johannessen, E. L., Andersson, H. W., Bjorngaard, J. H. og Pape, K. (2017). Anxiety and depression symptoms and alcohol use among adolescents - a cross sectional study of Norwegian secondary school students. BMC Public Health, 17. doi:10.1186/s12889-017-4389-2

Langton, E. G., Collishaw, S., Goodman, R., Pickles, A. og Maughan, B. (2011). An emerging income differential for adolescent emotional problems. Journal of Child Psychology and Psychiatry, 52(10), 1081-1088. doi:10.1111/j.1469-7610.2011.02447.x

Maughan, B., Collishaw, S. og Stringaris, A. (2013). Depression in childhood and adolescence. Journal of the Canadian Academy of Child \& Adolescent Psychiatry, 22(1), 35-40. Sótt af http://search.ebscohost.com/login. aspx?direct $=$ true $\& \mathrm{db}=$ aph $\& A N=85204932 \&$ site $=$ ehost-live

McGraw, K., Moore, S., Fuller, A. og Bates, G. (2008). Family, peer and school connectedness in final year secondary school students. Australian Psychologist, 43(1), 27-37. doi:10.1080/00050060701668637

Merry, S. N., Hetrick, S. E., Cox, G. R., Brudevold-Iversen,T., Bir,J.J. og McDowell, H. (2011). Psychological and educational interventions for preventing depression in children and adolescents. Cochrane Database of Systematic Reviews, 12. doi:10.1002/14651858.CD003380.pub3

Munoz, R. F., Beardslee,W. R. og Leykin,Y. (2012). Major depression can be prevented. American Psychologist, 67(4), 285-295. doi:10.1037/a0027666

Olweus, D. (1996). Bullying at school - Knowledge base and an effective intervention program. Í C. F. Ferris og T. Grisso (ritstjórar), Understanding aggressive behavior in children (bls. 265-276). doi:10.1111/j.1749-6632.1996. tb32527.x 
Perry-Parrish, C. og Zeman, J. (2011). Relations among sadness regulation, peer acceptance, and social functioning in early adolescence:The Role of Gender. Social Development, 20(1), 135-153. doi:10.1111/j.14679507.2009.00568.x

Roberts, R. E., Roberts, C. R. og Duong, H. T. (2009). Sleepless in adolescence: Prospective data on sleep deprivation, health and functioning. Journal of Adolescence, 32(5), 1045-1057. doi:10.1016/j.adolescence.2009.03.007

Rubenstein, L. M., Hamilton, J. L., Stange, J. P., Flynn, M., Abramson, L.Y. og Alloy, L. B. (2015). The cyclical nature of depressed mood and future risk: Depression, rumination, and deficits in emotional clarity in adolescent girls. Journal of Adolescence, 42, 68-76. doi:10.1016/j.adolescence.2015.03.015

Sigrún Daníelsdóttir, Védís Helga Eiríksdóttir og Salbjörg Bjarnadóttir (2017). Talnabrunnur 11(6). Sótt af https://www.landlaeknir.is/servlet/file/store93/item32745/Talnabrunnur_Agust_2017.pdf

Socialstyrelsen. (2016). Utvecklingen av psykisk ohälsa bland barn och unga vuxna. Till och med 2016. Stokkhólmur: Höfundur.

Stice, E., Shaw, H., Bohon, C., Marti, C. N. og Rohde, P. (2009). A meta-analytic review of depression prevention programs for children and adolescents: Factors that predict magnitude of intervention effects. Journal of Consulting and Clinical Psychology, 77(3), 486-503. doi:10.1037/a0015168

Sweeting, H., West, P.,Young, R. og Der, G. (2010). Can we explain increases in young people's psychological distress over time? Social Science and Medicine, 71(10), 1819-1830. doi:10.1016/j.socscimed.2010.08.012

Thapar, A., Collishaw, S., Pine, D. S. og Thapar, A. K. (2012). Depression in adolescence. Lancet, 379(9820), 1056-1067. doi:10.1016/s0140-6736(11)60871-4

Thorsteinsson, E. B., Loi, N. M., Sveinbjornsdottir, S. og Arnarsson, A. (2017). Sexual orientation among Icelandic year 10 adolescents: Changes in health and life satisfaction from 2006 to 2014. Scandinavian Journal of Psychology, 58(6), 530-540. doi:10.1111/sjop.12402

van den Eijnden, R. J. J. M., Lemmens, J. S. og Valkenburg, P. M. (2016). The social media disorder scale. Computers in Human Behavior, 61, 478-487. doi:10.1016/j.chb.2016.03.038

West, P. og Sweeting, H. (2003). Fifteen, female and stressed: Changing patterns of psychological distress over time. Journal of Child Psychology and Psychiatry, 44(3), 399-411.

Wiens, K., Williams, J.V. A., Lavorato, D. H., Duffy, A., Pringsheim, T. M., Sajobi, T. T. og Patten, S. B. (2017). Is the prevalence of major depression increasing in the Canadian adolescent population? Assessing trends from 2000 to 2014. Journal of Affective Disorders, 210, 22-26. doi:10.1016/j.jad.2016.11.018

Wiklund, M., Malmgren-Olsson, E. B., Ohman, A., Bergstrom, E. og Fjellman-Wiklund,A. (2012). Subjective health complaints in older adolescents are related to perceived stress, anxiety and gender - a cross-sectional school study in Northern Sweden. BMC Public Health, 12. doi:10.1186/1471-2458-12-993

Ársæll Arnarsson (2019).

Depurð meðal skólabarna á Íslandi

Netla - Veftímarit um uppeldi og menntun. Menntavísindasvið Háskóla Íslands.

Sótt af http://netla.hi.is/serrit/2019/altjodlegar_menntakannanir/01.pdf

DOI: https://doi.org/10.24270/serritnetla.2019.30 